\title{
Safe operation and reconstruction of urban water bodies in the park complexes
}

\author{
Yekaterina Plyusnina* and Aleksandra Ostiakova \\ Moscow State University of Civil Engineering, Yaroslavskoe shosse, 26, Moscow, 129337, Russia
}

\begin{abstract}
In the field of improvement of urban areas of General use, it is important to study the environmental problems of urban water bodies and to ensure the necessary level of sanitary maintenance and improvement of the water bodies themselves and the surrounding area. This article investigates the ecological state of the city pond in the park of Nakhabino in the Moscow region. At the moment, the condition of the pond is unsatisfactory in terms of both improvement and sanitary-hygienic and aesthetic condition. The purpose of the work is to analyze the existing negative environmental factors on the example of a water body, as well as to offer an option of ecological reconstruction and further safe operation. To achieve this goal, the analysis of available literature sources was carried out, a visual survey of the water body located in the Park was carried out. The article presents a description of the area of the pond and the Park, identified and listed the negative, influencing the contamination of pond and water quality factors. The necessary types of works on improvement and sanitary cleaning of the bowl of the pond and the coastal area are listed. As a result of a comprehensive analysis of the ecological status of the pond, a model of the pond named after Karbyshev in Nakhabino was created, a version of its ecological reconstruction was proposed. The model is presented at the Moscow youth exhibition. The conducted research has a certain practical value. Subsequently, it is planned to present the project of ecological reconstruction of this water body for its reconstruction to the territorial authorities.
\end{abstract}

\section{Introduction}

Environmental safety of water resources in Russia is part of the overall state security. The safety of environmental management is ensured by environmental programs that are linked to and conditioned by the socio-economic development of society. Existing environmental programs are aimed at reducing discharges and emissions from sources of impact to the environment, to address the issues of preserving the normal ecological state of the environment at the national level and in municipalities [1-3].

The problems of environmental (urban) protection cannot be solved without a permanent mechanism of prevention, localization and elimination of negative impacts from reconstruction activities. One of the elements of this mechanism is the development of

\footnotetext{
* Corresponding author: pluskott@yandex.ru, alex-ost2006@ya.ru
} 
environmental and resource-reproducing measures in urban planning. This also applies to water bodies in the recreational areas of cities. Urban water bodies are under the constant influence of anthropogenic factors. Feature of natural balance of lakes and ponds is the slow water exchange, the tendency to sedimentation and a gradual decrease in the area of the reservoir, which affects the quality of water in the reservoir and its use for the needs of drinking water, sanitation facilities, swimming vacationers, the change in the qualitative and quantitative composition of flora and fauna in the pond and coastal area. therefore, it is important to monitor the status of water bodies and their timely rehabilitation.

\section{Literature review}

According to the world health organization, the impact of the environment on the health of the world's population is constantly growing. As follows from the state report "On the sanitary and epidemiological situation in the Russian Federation in 2010", the situation with the state of surface and underground sources of centralized drinking water supply and water quality in places of water intake is unsatisfactory and does not comply with sanitary rules and standards (36.8 \% of surface sources and $16.4 \%$ of underground) [4]. In Russia, there is a state program "Environmental Protection" for 2012-2020 [5], which provides for monitoring and improving the quality of water resources, regional programs, for example, since 2012, the state program of the city of Moscow "Development of the leisure and tourism industry for 2012-2018 " [6]. The purpose of this program is to create an infrastructure of a high level of comfort of the urban environment for recreation and tourism in the city of Moscow, including the rehabilitation of ponds located in the parks of culture and recreation of the city of Moscow and the adaptation of urban water bodies to ensure the rest of the city population. As shown by social surveys [7], the need for quality rest due to the negative impact of the urban environment on the health of the population continues to increase. Operation of decorative ponds is also provided by the Program [6] within the framework of the subprogram "recreation industry in the public areas", including the section "Protection and overhaul of surface waters of the city of Moscow". Works on this section are performed by sue "Mosvodostok".

Modern scientific researches $[8,9]$ are devoted to improvement, sanitary cleaning of shores of reservoirs and maintenance of water quality in them. At the current rate of urbanization significantly reduced the area with a natural landscape, which leads to environmental degradation. In order to reduce these negative phenomena, as well as to combat pollution and noise, special measures are envisaged [10].

In the Moscow region there are also programs in which projects and works on the development of Park areas are carried out. For example, in Krasnogorsk city administration is working on the improvement of Park areas, including ponds and lakes, which in the area of Krasnogorsk a lot [11].

\section{Materials and methods}

The shores of water bodies-one of the most visited places of rest of the city's population. In addition to purely aesthetic and functional elements of the urban environment, water bodies have sanitary and hygienic significance, improving the microclimatic conditions of the coastal strip. Water bodies in combination with green areas - one of the most important elements of the improvement of the urban area.

On the basis of visual inspection of the territory of the water body - pond in the Park complex named after the largest domestic scientist-engineer, Soviet fortifier, Lieutenant General, doctor of military Sciences, Professor of the Military Academy of the General 
staff of the red army, Hero of the Soviet Union D. M. Karbyshev in the village of Nakhabino of Krasnogorsk district of the Moscow region revealed the unsatisfactory state of its territory, including the shores, water quality in this water body and the lack of any improvement in the vicinity of the pond.

The pond with an area of $2100 \mathrm{~m} 2$ is used as a recreation facility, closes the system of ponds formed from the tributary of the Nakhabinka river, that is, it is a non-flowing pond. The Park is one of the favorite places of rest for residents of Nakhabino. The Park pond is called the Upper one. He ducked connects with another large pond, called Lower. The Lower pond was adjoined by a large glade [12], now in the Northern part of the coastal territory of the pond there is a garbage Playground and a Parking lot. In 2018 in the village of Nakhabino is home to more than 43400 residents, about a quarter of them periodically visit the Park. We can assume that on average, 1 / 40th part of the inhabitants, that is 1000 people makes a walk in the Park named Karbysheva daily and at weekends, weekends can be more. There are statistics that the area of the Park for the weekend at different times of the year can be a few tens or even hundreds of kilograms of household waste. Garbage collection is carried out weekly by municipal services, each season the General cleaning of the Park.

According to 2016 data, the indicators of water quality in the pond, although not exceeding the MPC, still differ in stiffness (6.4 at a rate of 7.0), turbidity (2.5 EMF at a rate of $2.6 \mathrm{EMF})$, a large number of fluorides $(1.3 \mathrm{mg} / \mathrm{l}$ at a rate of $1.5 \mathrm{mg} / \mathrm{l})$ and iron $(0.24 \mathrm{mg} / \mathrm{l}$ at a rate of $0.3 \mathrm{mg} / \mathrm{l}$ ). For other indicators (taste, smell, color, ammonia, nitrites, nitrates, sulfates, chlorides, manganese) indicators are much lower than the MAC norm. And the quality indicators depend not so much on the type of bottom soil, relief, climatic conditions, but on the volume and quality of water entering the pond from the urban area.

The pond is fed by both surface and filtration waters. First of all, this applies to the surrounding residential areas. From the surface through the storm sewer comes atmospheric water in the form of rain and melted snow, or in the absence of storm drainage and drainage water flows by gravity to the lowest points of relief in the same pond, the average monthly rainfall in the Krasnogorsk region $57 \mathrm{~mm}$, the least amount of precipitation in March (32 $\mathrm{mm})$, the most - in July $(89 \mathrm{~mm})$, the average annual volume of evaporation $434 \mathrm{~mm}$, part of water is infiltrated into the ground. Part of the water can also come from the city's sewage system through the Sewerage system. With underground waters by filtering the dissolved and slightly soluble pollutants - chemical (inorganic and organic) substances, including pesticides, mineral fertilizers arrive. Incoming wastewater from urban areas (about 16\% of the total flow) may contain heavy metals (from transport, industrial enterprises), be biologically contaminated (helminths, bacteria, microbes, harmful to human and animal health, pollution with phytoplankton and algae), as well as physically (thermal, electromagnetic pollution), mechanically (grass overgrowth of the pond bowl, litter, solid waste landfills, increasing the content of solid mineral particles, suspensions or other insoluble particles in water, etc.). resulting in increased water turbidity, water in the pond as a result of erosion of the coast) and radiation contaminated in the absence of the necessary measures and devices for water purification.

In the case of cleaning the pond from the existing pollution of various origins, the pond will become a well-maintained and aesthetic object of urban infrastructure, meet the sanitary requirements [13], but so far it has not been reconstructed and improved (Fig. 1). 

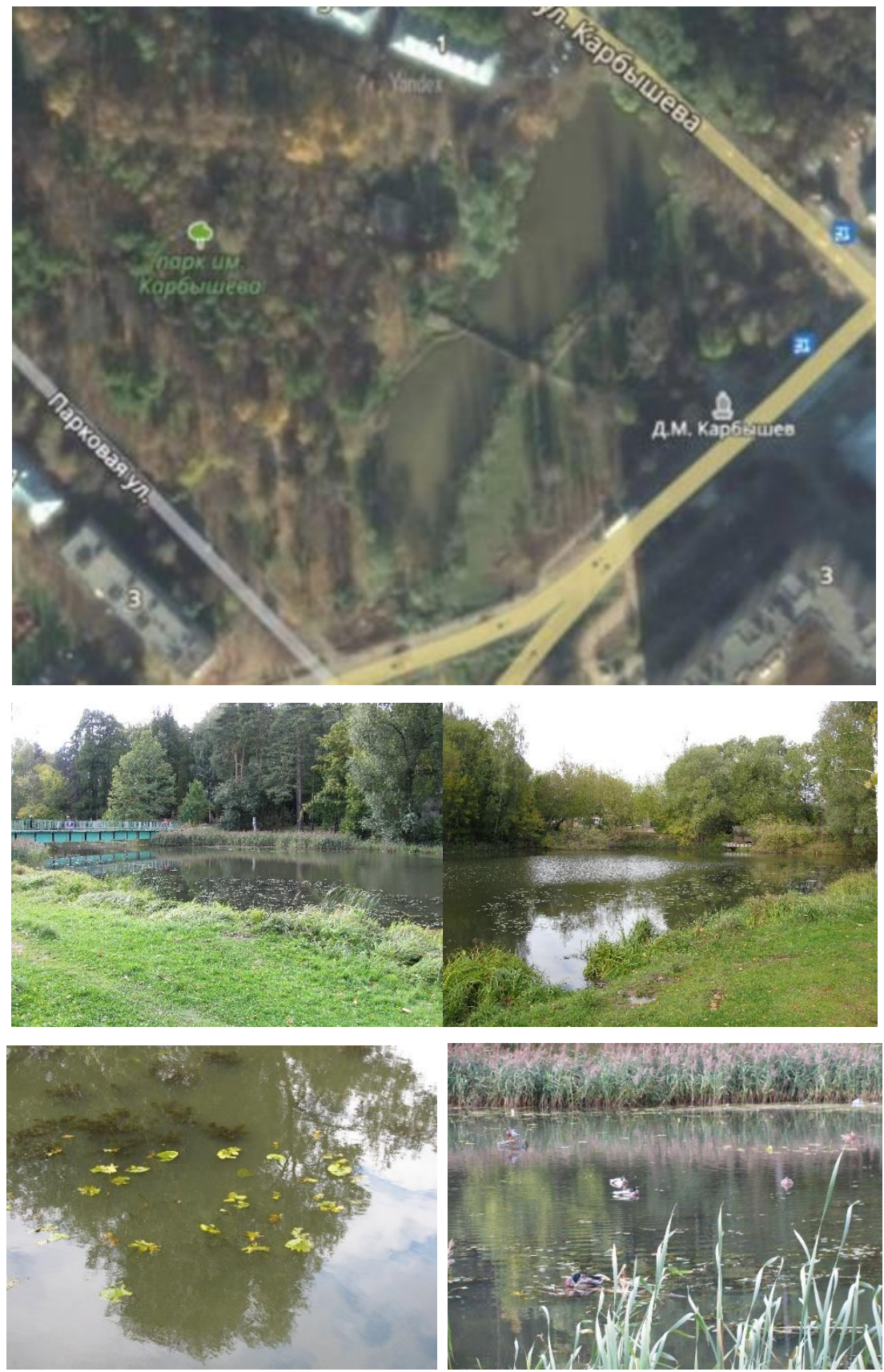

Fig. 1. Photo of Park of a name Karbysheva from satellite, and photos of the pond in this Park.

In the Park near the pond at the moment there are no paths, benches, lighting, small architectural forms - all those necessary components that are prescribed in the code of rules "Landscaping" [14]. The most important thing to do to maintain the normal ecological condition of the pond is to increase its flow, water exchange, to change the temperature and humidity conditions for the better, to exclude waterlogging of the pond area [15], as well as other works.

The results of the improvement should include the possibility of walking around the pond. The necessary works in the improvement of urban water bodies include: 
- clean the water from the vegetation,

- strengthening of banks by engineering methods, for example, the device of a retaining wall, with planting on slopes of plants with different root systems,

- filling the reservoir bowl with clean water up to the design mark,

- installation of "smart" lighting,

- arrangement of paths around the pond,

- installation of benches and possibly small architectural forms,

- planting additional bushes and trees around the pond.

It is necessary to clarify in case of implementation of design on this project the volumes of these works, as well as to take measures for purification of water contaminated from impurities in the future. It is also desirable to use devices for forced water exchange and aeration of water in order to maintain the normal oxygen regime and, possibly, stocking the reservoir.

An important part of the ecological reconstruction of the water body is the undisturbed, immutability of the existing ecosystem.

\section{Research results}

Legislative and regulatory documents of the Federal and regional levels, as well as scientific articles and monographs on environmental safety, improvement and maintenance of urban water bodies in a normal ecological state are analyzed. On the basis of visual inspection of the Park territory and analysis of information sources the conclusion about the state of the coastal area of the pond and the water quality in it is made. The proposal with the list of necessary works on ecological reconstruction of the pond territory on condition of its ecosystem preservation is made.

A model of ecological reconstruction of the water body in the Park named after Karbyshev in the form of a layout (Fig. 2), which was presented at the exhibition "Moscow through the eyes of young urban planners."

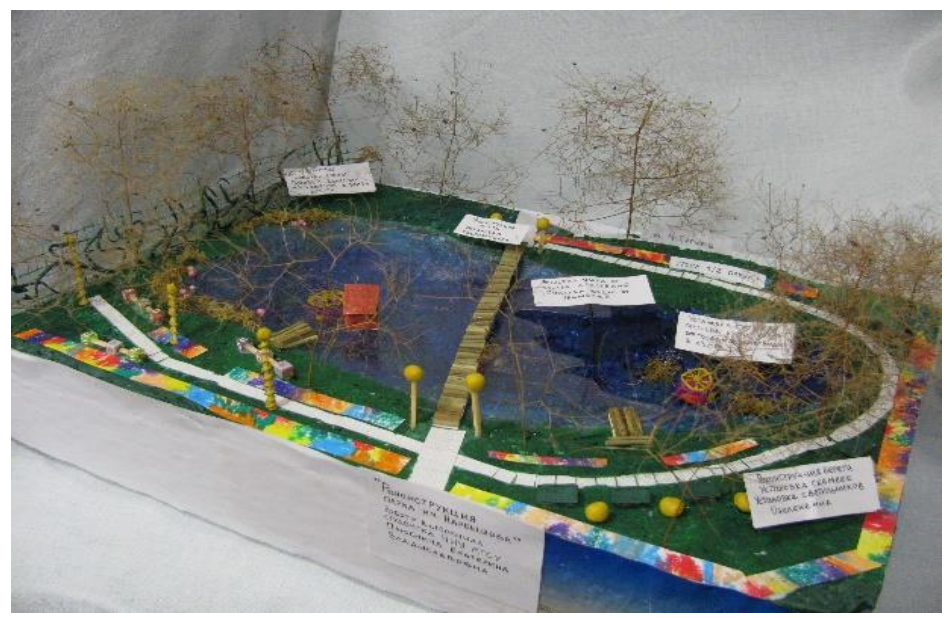

Fig. 2. Model of ecological reconstruction of the Karbyshev Park in Nakhabino.

\section{Summary}

Planning and implementation of measures to improve the environment will have a positive impact on the health of the population living near the Park. The pond of the Park named after Karbyshev as an object of recreational town-planning zone as a result of ecological 
reconstruction will perform its functions much better and have a positive impact on the surrounding area in terms of improving temperature and humidity exchange.

The study is necessary to improve the overall environmental condition of the area. In addition to presenting the project of ecological reconstruction of this water body at the exhibitions, it is planned to popularize and try to include it in the city programs for its reconstruction.

\section{References}

1. http://fb.ru/article/284396/ekologicheskie-programmyi-i-proektyi-v-rossii-federalnayatselevaya-programma-ohrana-ozera-baykal.

2. Ye.V. Neverova-Dziopak, L.I. Tsvetkova, S.V. Makarova and A.V. Kiselev, Modern probl. of sc. and ed. 3, 15 (2012)

3. V.A. Rumiantsev, L.N. Kryukov, Soc. Env. Devel. 4, 129 (2017)

4. L.I. Elpiner, Hyg. and sanit. 6, 38 (2013)

5. http://government.ru/programs/205/events.

6. Order of the Government of Moscow of 07.10.2011 No. 476-PP "About the approval of the State program of the city of Moscow "Development of the industry of rest and tourism for 2012-2018"

7. http://vid1.rian.ru/ig/ratings/Parks_results.pdf

8. Ye.K. Balova, V.V. Volshanik, A.L. Suzdaleva, Full-scale study of anthropogenic impact on water quality in the river Protva. In the collection of materials: Integration, partnership and innovation in building science and education collection of materials of the international scientific conference. National research Moscow state University of civil engineering. 2017. P. 859

9. V.V. Kuzovlev, I.L. Grigoryeva, A.B. Komissarov, Ye.A. Chekmareva, The content of nutrients in the water of lakes Pesvo and Udomlya / / In the collection: Organic matter and nutrients in inland waters and sea waters Proceedings of the VI all-Russian Symposium with international participation. 2017. P. 120

10. http://allformgsu.ru/publ/kompleksnoe__inzhenernoe_blagoustrojstvo/estestvennye _i_iskusstvennye_vodoemy_na_gorodskoj_territorii/12-1-0-57

11. http://krasnogorsk-adm/news/straregiyu-razvitiya-parkovyh-territotiy-krasnogorskapredstavil-glava-gorodskogo-okruga-radiy-habirov.html

12. Ye.A. Shevchenko, B.I. Privalenko, Nakhabino (Artel-Art, Moscow, 2004)

13. SanPin 2.1.5.980-00 2.1.5. Water disposal of settlements, sanitary protection of water bodies. Hygienic requirements for surface water protection. Sanitary rules and regulations. Ministry Of Health. Moscow (2000)

14. SP 82.13330.2016 Landscaping.

15. V.S. Borovkov, V.V. Volshanik, Water and ecol.: probl. and solut. 3, 67 (2016) 